\title{
Interaction of the Faroe Bank Channel overflow with Iceland Basin intermediate waters
}

\author{
Jenny E. Ullgren, ${ }^{1}$ Ilker Fer, ${ }^{2}$ Elin Darelius, ${ }^{2}$ and Nicholas Beaird ${ }^{3}$ \\ Received 17 September 2013; revised 13 December 2013; accepted 14 December 2013; published 10 January 2014.
}

[1] The narrow and deep Faroe Bank Channel (FBC) is an important pathway for cold, dense waters from the Nordic Seas to flow across the Iceland-Scotland ridge into the North Atlantic. The swift, turbulent FBC overflow is associated with strong vertical mixing. Hydrographic profiles from a shipboard survey and two Slocum electric gliders deployed during a cruise in May-June 2012 show an intermediate water mass characterized by low salinity and low oxygen concentration between the upper waters of Atlantic origin and the dense overflow water. A weak low-salinity signal originating north-east of Iceland is discernible at the exit of the FBC, but smeared out by intense mixing. Further west (downstream) marked salinity and oxygen minima are found, which we hypothesize are indicators of a mixture of Labrador Sea Water and Intermediate Water from the Iceland Basin. Water mass characteristics vary strongly on short time scales. Low-salinity, lowoxygen water in the stratified interface above the overflow plume is shown to move along isopycnals toward the Iceland-Faroe Front as a result of eddy stirring and a secondary, transverse circulation in the plume interface. The interaction of low-salinity, low-oxygen intermediate waters with the overflow plume already at a short distance downstream of the sill, here reported for the first time, affects the final properties of the overflow waters through entrainment and mixing.

Citation: Ullgren, J. E., I. Fer, E. Darelius, and N. Beaird (2014), Interaction of the Faroe Bank Channel overflow with Iceland Basin intermediate waters, J. Geophys. Res. Oceans, 119, 228-240, doi:10.1002/2013JC009437.

\section{Introduction}

[2] Deep and bottom waters in the Nordic Seas are trapped behind the Greenland-Scotland Ridge, and flow out into the North Atlantic Ocean through a few deeper channels. About one third of the total overflow transport takes place through the Faroe Bank Channel (FBC, see Figure 1a), a narrow $(\sim 15 \mathrm{~km})$ channel with a sill depth of $840 \mathrm{~m}$ [Hansen and Østerhus, 2007]. The water mass produced when the overflow waters mix with the overlying Atlantic water forms an important component of North Atlantic Deep Water, a voluminous deep water mass that spreads through much of the world ocean as a part of the global thermohaline circulation [Johnson, 2008; Hansen et al., 2004].

\subsection{Water Masses and Circulation Patterns}

[3] The water mass distributions and circulation patterns in the region are complex. There is large temporal variabili-

\footnotetext{
${ }^{1}$ Geophysical Institute, University of Bergen, Bergen, Norway.

${ }^{2}$ Geophysical Institute, University of Bergen and Bjerknes Centre for Climate Research, Bergen, Norway.

${ }^{3}$ Woods Hole Oceanographic Institution, Woods Hole, Massachusetts, USA.

Corresponding author: J. E. Ullgren, Geophysical Institute, University of Bergen, Allegaten 70, NO-5007 Bergen, Norway. (ullgren.j@gmail.com)

ty associated with the source waters and in the proportions of the different water masses that constitute the water column in the Faroese Channels [Hansen and Østerhus, 2000; Turrell et al., 1999]. Place names and typical circulation patterns are summarized in Figure 1. Two surface water masses are found in the area (Table 1): North Atlantic Water (NAW), the warmest and most saline surface water, and Modified North Atlantic Water (MNAW) [e.g., Turrell et al., 1999]. We will refer to NAW and MNAW together as "Atlantic waters." In the thermocline, at the base of the surface layer, profiles generally converge onto a straight mixing line in potential temperature $(\theta)$ and salinity $(S)$ space connecting the upper, Atlantic waters to the deep waters of Nordic Seas origin. The dense water that takes part in the overflow is often described simply as Norwegian Sea Deep Water (NSDW) [e.g., Borenäs et al., 2001], but in fact consists of a portion of NSDW mixed to variable degrees with intermediate water in the Faroe Shetland Channel (FSC).

[4] The water mass that mixes with NSDW - in about equal parts according to Fogelqvist et al. [2003] - to create the bottom water in the Faroese Channels is Norwegian Sea Arctic Intermediate Water (NSAIW) [Blindheim, 1990; Martin, 1993], marked by a salinity minimum at the potential density anomaly $\sigma_{\theta} \sim 28.0 \mathrm{~kg} \mathrm{~m}^{-3}$. In the FBC, the presence of NSAIW just above the bottom water is seen as a slight "hook" on the $\theta-S$ curve centered at about $0^{\circ} \mathrm{C}$ [Borenäs et al., 2001]. 


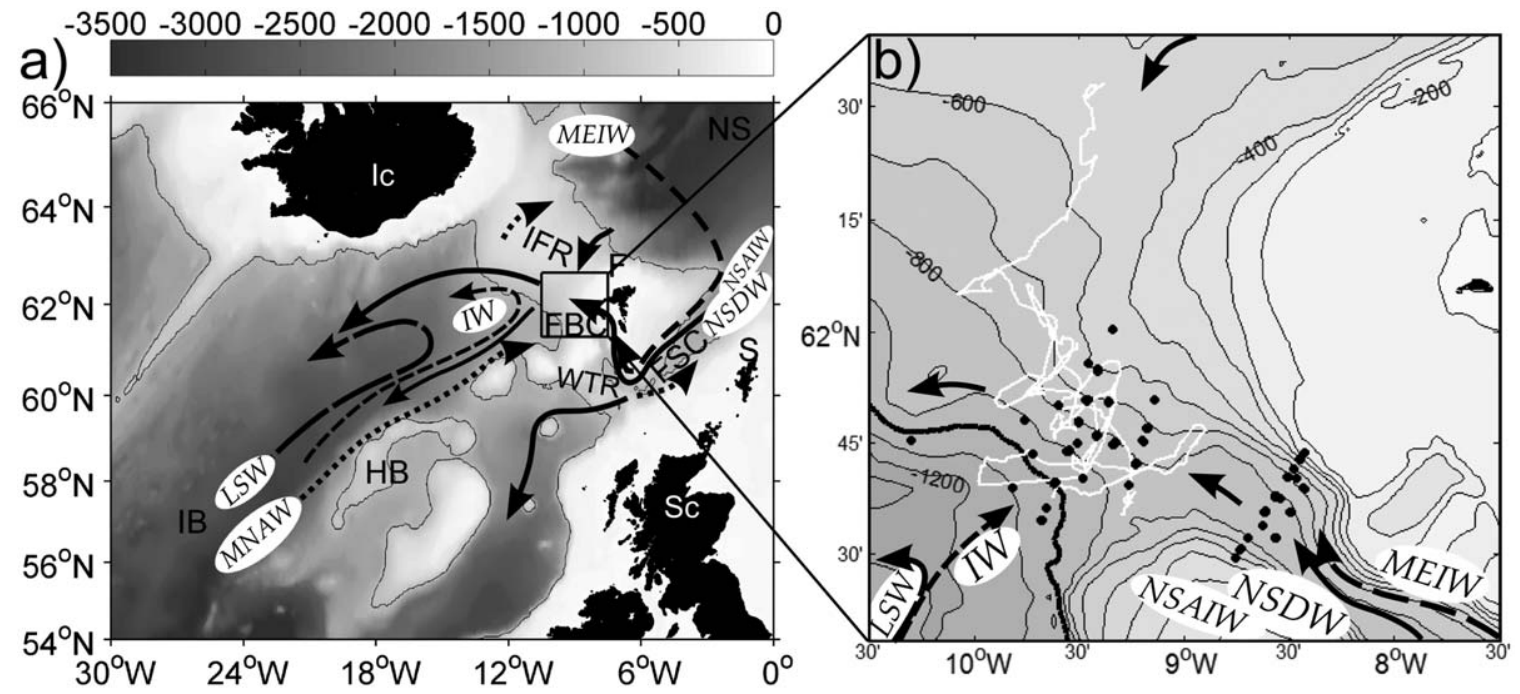

Figure 1. (a) Overview map of the region, with the Faroe Islands (F), Shetland Islands (S), Scotland (Sc), Iceland (Ic), Faroe-Shetland Channel (FSC), Faroe Bank Channel (FBC), Iceland-Faroe Ridge (IFR), Wyville-Thomson Ridge (WTR), Hatton Bank (HB), Iceland Basin (IB), and the Nordic Seas (NS) labeled. Some of the important water masses discussed are shown (see Table 1) - deep overflows as whole arrows, intermediate waters as dashed, and surface water as dotted arrows. Bathymetry shaded, see scale on top, with the $1000 \mathrm{~m}$ contour drawn as a thin black line. (b) Close-up of the study area (marked by black box in Figure 1a), with overview of measurements during the research cruise on R. V. Håkon Mosby in May-June 2012. Glider tracks in white, CTD stations as black dots (for more details, see Figure 2). Whole arrows indicate deep overflows (NSDW with NSAIW) and dashed arrows intermediate water masses (MEIW, IW, LSW). Bathymetry shaded as in Figure 1a, with black contours at 100 $\mathrm{m}$ intervals, the $1000 \mathrm{~m}$ contour bold.

[5] A lighter intermediate water mass is typically present in the FSC, and can be observed in the FBC in a diluted form. This fresh water mass is a mixture of several source waters in the region of the East Iceland Current and labeled Modified East Iceland Water (MEIW) by Read and Gould [1992], and we will use this name hereafter. The MEIW signature in the $\mathrm{FBC}$ is weak, partly because much of the MEIW recirculates within the FSC, and partly because of mixing [Hansen and Østerhus, 2000]. The MEIW can, however, be recognized as a salinity minimum or an inflection point between 2 and $5.5^{\circ} \mathrm{C}$. A noticeable influence of MEIW is typically found on the Faroe Islands (i.e., the northern) side of the FBC but not on the (southern) Faroe Bank side [Dooley and Meincke, 1981; Borenäs et al., 2001].

[6] In the Iceland Basin, a water mass known simply as Intermediate Water (IW) is "biogeochemically defined"

Table 1. Summary of Water Masses in the Study Region ${ }^{\text {a }}$

\begin{tabular}{|c|c|c|c|c|c|c|}
\hline Water Mass Name & Acronym & $\theta\left({ }^{\circ} \mathrm{C}\right)$ & $\mathrm{S}$ & $\sigma_{\theta}\left(\mathrm{kg} \mathrm{m}^{-3}\right)$ & $\mathrm{O}_{2}\left(\mu \mathrm{mol} \mathrm{kg}{ }^{-1}\right)$ & Comments \\
\hline North Atlantic Water & NAW $^{\mathrm{b}}$ & $>8$ & $>35.30$ & $<27.45$ & $265-270$ & \\
\hline Modified North Atlantic Water & MNAW $^{\mathrm{c}}$ & $6.5-8$ & $35.10-35.30$ & $27.45-27.65$ & & \\
\hline Intermediate Water & $\mathrm{IW}^{\mathrm{d}}$ & 6.5 & 35.1 & $\sim 27.6$ & 220 & $\mathrm{O}_{2}$ minimum \\
\hline Modified East Iceland Water & MEIW $^{\mathrm{e}}$ & $1-3$ & $34.70-34.90$ & $\sim 27.8$ & 300 & $\begin{array}{l}S \text { minimum or } \\
\text { inflection point }\end{array}$ \\
\hline Labrador Sea Water & $\mathrm{LSW}^{\mathrm{f}}$ & $3.0-3.5$ & $34.8-34.9$ & $27.7-27.8$ & $270-280$ & $S$ minimum. \\
\hline Norwegian Sea Deep Water & $\mathrm{NSDW}^{\mathrm{h}}$ & $<-0.5$ & $\sim 34.91$ & $>28.0$ & $297-299$ & \\
\hline
\end{tabular}

${ }^{a}$ Water mass names and acronyms are given together with the potential temperature $(\theta)$ potential density anomaly $\left(\sigma_{\theta}\right)$ salinity $(S)$ and, where known, oxygen concentrations $\left(\mathrm{O}_{2}\right)$ levels. Identifying characteristics are mentioned in the comments. References, and alternative names used in literature: see footnotes.

${ }^{\mathrm{b}}$ Read and Gould [1992]; NEAW in Fogelqvist et al. [2003].

${ }^{\mathrm{c}}$ Read and Gould [1992], Hansen and Østerhus [2000], and Mauritzen et al. [2005].

${ }^{\mathrm{d}}$ Stoll et al. [1996] and van Aken and de Boer [1995].

${ }^{\mathrm{e}}$ After Read and Gould [1992]. Core $\theta$-S range [Hansen and Østerhus, 2000; Fogelqvist et al., 2003]. Corresponds to North Icelandic (Winter) Water/ Arctic Intermediate Water (NI/AI) of Meincke [1978], Borenäs et al. [2001], AI of Dooley and Meincke [1981], and AI/NIW of Turrell et al. [1999] and Mauritzen et al. [2005] $\left(2<\theta<5.5^{\circ} \mathrm{C}\right.$ in FSC).

${ }^{\mathrm{f}}$ Properties characteristic of LSW in the Iceland Basin [Fogelqvist et al., 2003]; cf. Sarafanov et al. [2012] and van Aken and de Boer [1995].

${ }^{\mathrm{g}}$ Hansen and Østerhus [2000] and Fogelqvist et al. [2003]; NSI in Borenäs et al. [2001], AIW in Blindheim [1990].

${ }^{\mathrm{h}}$ Borenäs et al. [2001], Hansen and Østerhus [2000], and Fogelqvist et al. [2003]; FSCBW (mixture of NSDW and NSAIW) in Turrell et al. [1999]. 
[van Aken and de Boer, 1995] — characterized by its oxygen minimum, and $\mathrm{Si}$ and $\mathrm{NO}_{3}$ maxima, rather than by its $\theta-S$ properties. Below it, minima in salinity and potential vorticity mark the uppermost of the deep water masses, Labrador Sea Water (LSW) [see Figure 1a; Talley and McCartney, 1982; van Aken and Becker, 1996].

\subsection{Overflow and Water Mass Modification}

[7] Along the path of the swift, turbulent overflow, transverse circulations and mesoscale variability lead to interaction between water masses, and substantial water mass modification occurs as a result of entrainment and mixing. A detailed water mass mixing analysis based on multiple hydrochemical variables has been performed by Fogelqvist et al. [2003].

[8] The FBC overflow is energetic, with core velocities exceeding $100 \mathrm{~cm} \mathrm{~s}^{-1}$ [Hansen and Østerhus, 2000], and cold; water colder than $0^{\circ} \mathrm{C}$ is normally present within the FBC [Borenäs and Lundberg, 1988]. In the vicinity of the saddle point in the FBC, the overflow is constrained by the sloping topography on either side, whereas it flows along the Iceland-Faroe slope farther downstream. Isopycnals on average tilt down toward the Faroe Bank side of the channel (south) where they are pinched together, while they are vertically spread out on the Faroe Islands side. The transport of water colder than $3^{\circ} \mathrm{C}$ - the isotherm commonly used to delimit the plume [Borenäs and Lundberg, 2004]is estimated to about $1.9 \pm 0.4 \mathrm{~Sv}\left(1 \mathrm{~Sv}=10^{6} \mathrm{~m}^{3} \mathrm{~s}^{-1}\right)$ [Saunders, 1990; Hansen et al., 2001].

[9] The overflow widens and deepens with distance from the sill, and as a result of entrainment of lighter water the transport in the coldest temperature class decreases downstream. Darelius et al. [2011] report that some $100 \mathrm{~km}$ downstream of the sill, none of the water colder than $0^{\circ} \mathrm{C}$ remains, and the transport below the $3^{\circ} \mathrm{C}$ isotherm has decreased, reflecting a shift toward transport in higher temperature classes. The decrease in volume transport of the coldest water is associated with a reduction in height of the outflow plume. Duncan et al. [2003] found that the thickness of the well-mixed bottom layer decreased from $>200$ $\mathrm{m}$ near the sill to 60-70 m some $80 \mathrm{~km}$ downstream.

[10] The first microstructure survey of the FBC overflow revealed a highly turbulent plume [Fer et al., 2010]. Particularly, intense mixing has been observed some $80-100 \mathrm{~km}$ downstream of the FBC sill [Mauritzen et al., 2005; Fer et al., 2010; Beaird et al., 2012]. In the channel, there is a pronounced secondary, transverse circulation, contained by the side walls, whereby Ekman transport in the bottom boundary layer and flow in the opposite direction in the interface above the plume lead to a spiral velocity pattern [Johnson and Sanford, 1992]. Recent studies have shown that a similar transverse circulation also exists downstream on the slope [Seim and Fer, 2011].

[11] The plume is furthermore characterized by mesoscale variability [Geyer et al., 2006; Darelius et al., 2011], reflected in enhanced sea level variability and eddy kinetic energy observed downstream of the sill [Høyer and Quadfasel, 2001; Darelius et al., 2013]. Darelius et al. [2011] found that the periodicity in near-bottom temperature and velocity varied between 2.5 and 5 days, in response to a train of alternating cyclones and anticyclones with length scales of $75-180 \mathrm{~km}$ moving along the slope at phase speeds of $25-60 \mathrm{~cm} \mathrm{~s}^{-1}$. The eddies are associated with 100-200 m thick boluses of cold water that, however, do not coincide with eddy cores [Darelius et al., 2011].

\subsection{Aim}

[12] The $\theta-S$ relationship in the FBC is typically tight. However, examination of hydrographic data from a research cruise in 2012 showed marked $S$ and $\mathrm{O}_{2}$ concentration anomalies at intermediate density levels. The aim of this study is to describe and explain these anomalies. In particular, we hypothesize that $\mathrm{O}_{2}$ and $S$ anomalies above the overflow plume are propagated along the isopycnals north toward the Iceland-Faroe Front, faciliated by mesoscale variability. In this paper, we therefore present a detailed analysis of the currents and water masses of the FBC on the basis of shipboard and glider observations from the 2012 survey, complemented by observations from 2008 [Fer et al., 2010], and data from several years of Seaglider surveys [Beaird et al., 2013]. The data collection and processing are described in section 2. The site of the 2012 survey is close to the second sill of the FBC, and the measurements cover the exit of the FBC toward the point where the plume bifurcates [Beaird et al., 2013], a region known for enhanced mixing [Mauritzen et al., 2005; Fer et al., 2010] and hence water mass transformation. The spatial distribution of water mass characteristics is presented in section 3.1. and its temporal variability in section 3.3. The findings are discussed and summarized in sections 4. and 5., respectively.

\section{Data}

[13] A research cruise was undertaken on the research vessel Håkon Mosby in May-June 2012 to measure turbulence and mixing in the overflow plume, at time scales resolving the dominant 3-4 day mesoscale variability. The survey also aimed to resolve the cross-plume secondary circulation in order to quantify its influence on mixing. The sampling was made using ship-based hydrography, current, and microstructure profiling as well as underwater gliders. A summary of the relative time of different deployments is given in Figure 3. Detailed information about the observational programme of the 2012 cruise is given below, excluding the microstructure measurements which are the topic of a separate study. Additional data include measurements from a research cruise in 2008 [Fer et al., 2010], and from a 3 year (2006-2009) Seaglider programme in the Iceland-Faroe Ridge (IFR) region [Beaird et al., 2013].

\subsection{Hydrography}

[14] Full-depth hydrographic casts were made with a SBE 911plus Conductivity-Temperature-Depth (CTD) system equipped with an oxygen sensor, a fluorometer, a transmissometer, and an altimeter (pinger) that allowed for sampling close to the seabed. In this paper, we will present results from the measurements of salinity, temperature, and oxygen concentration; fluorescence and turbidity data are not discussed here. No other water mass properties (such as nutrients) were sampled during the cruise. A total of 146 CTD profiles were taken during the cruise (Figures $1 \mathrm{~b}$ and 2), mainly along five repeat transects, each including 3-9 stations.

[15] Sections A, B, and C, located northwest of the sill crest-approximately $23 \mathrm{~km}, 57 \mathrm{~km}$, and $74 \mathrm{~km}$ downstream, respectively - were the three main transects. As the 


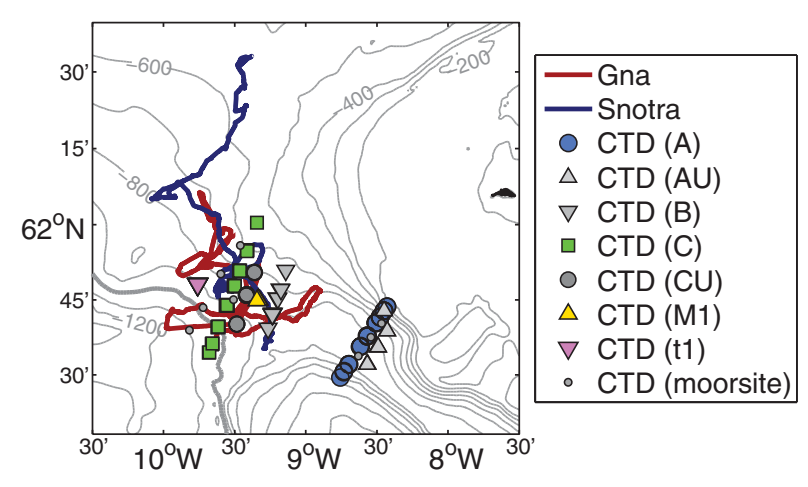

Figure 2. Map of the study area, cf. Figure 1b, with details of measurements during the research cruise on R. V. Håkon Mosby in May-June 2012, see legend on the right. Bathymetry at $200 \mathrm{~m}$ intervals shown as gray contours; 1000 m contour bold.

ship repositioned between the occupations of sections A and C, additional "upper" sections AU and CU, respectively, were taken about $5 \mathrm{~km}$ upstream, each with three stations (Figure 2).

[16] Section A was first occupied on 31 May-1 June (Figure 3). About a week later, section A and AU were repeated four and three times, respectively, between 9 and 12 June, continuously for $60 \mathrm{~h}$. Section B was visited twice, about a week apart. After the second occupation, a short time series station with six profiles at approximately $2 \mathrm{~h}$ intervals was taken with the ship maintaining position at B4. Section C, further downstream, was repeated five times over the course of $70 \mathrm{~h}$, in alternation with the upstream section CU. In addition, further repeat measurements were taken at two of the $\mathrm{C}$ and one of the CU stations.

\subsection{Current Profiling}

[17] A lowered acoustic Doppler current profiler (LADCP) system was mounted on the CTD rosette: two $300 \mathrm{kHz}$ Sentinel Workhorse ADCPs from Teledyne RD Instruments, one downward looking (master) and one upward looking (slave), sampling synchronously with a bin size of $8 \mathrm{~m}$. Current profiles were collected at 143 out of the 146 hydrographic stations. Processing of the LADCP data was done using the velocity inversion methodology implemented in the Lamont-Doherty Earth Observatory (LDEO) software [Thurnherr, 2011], constrained by the differential-GPS fixes of the vessel and the upper $500 \mathrm{~m}$ current profiles from the vessel-mounted ADCP. Tidal velocities at the times and locations of LADCP-profiles were computed using the Tidal Model Driver (TMD) tool- box based on the Oregon State University Tidal Prediction Software [Egbert and Erofeeva, 2002] and the barotropic tidal model for the European Shelf [Egbert et al., 2010].

\subsection{Underwater Gliders}

[18] Underwater gliders are autonomous vehicles propelled through buoyancy control and moving through the ocean along a see-saw trajectory [Eriksen et al., 2001; Jones et al., 2005]. Two Slocum electric gliders, Snotra and Gnå, from Teledyne Webb Research [Schofield et al., 2007], pressure rated to $1000 \mathrm{~m}$, were deployed during the 2012 cruise. Both gliders were equipped with a Seabird SBE-41 CTD (unpumped). One glider, Gnå, in addition had a MicroRider turbulence instrument (Rockland Scientific Int.) mounted in a bracket on top of the glider. The microstructure measurements from the glider are reported in a recent methods paper (I. Fer, A. K. Peterson, and J. E. Ullgren, Microstructure measurements from an underwater glider in the turbulent Faroe Bank Channel overflow, submitted to Journal of Atmospheric and Oceanic Technology, 2013). Glider data were post-processed using Matlab. Salinity was derived from the measured parameters after correcting for the thermal lag of the conductivity cell using a method proposed by Garau et al. [2011].

[19] For the gliders to spend as much time as possible in the plume and interface, without compromising the positioning - the glider's location is only known exactly when it is at the surface and receiving a GPS fix-the gliders were instructed to perform a full-depth dive followed by a climb only to $450 \mathrm{~m}$, from where they would immediately perform a second dive to the maximum depth before returning to the surface. Such "W"-shaped dives took on average 1.5 times longer to complete than a single dive in the same depth range.

[20] In this paper, we also present some data from Seagliders deployed in the IFR region between 2006 and 2009 by the University of Washington; for more information about that measurement programme, see Beaird et al. [2013]. The Seagliders were equipped with a Seabird 43 (SBE43) Clark-type oxygen electrode. Like the Seaglider CTD, the SBE43 is un-pumped, and speed dependent corrections have been applied to account for flushing speed past the sensor membrane. A simple exponential correction is used based on oxygen measurements taken in a controlled flow tank [Nicholson, 2009, Appendix A]. The sensors are calibrated yearly, but are known to drift over time [Nicholson et al., 2008]. In this study, oxygen observations are used for water mass identification, not detailed biological or chemical analysis. As such, a simple correction is applied to each oxygen profile to set the surface (top $10 \mathrm{~m}$

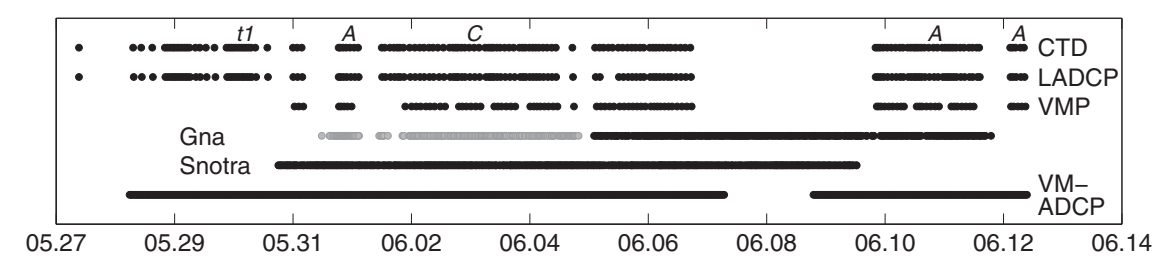

Figure 3. Time coverage of different observations during R. V. Håkon Mosby cruise in 2012. Type of measurement is given next to each line, and specific CTD/LADCP/VMP sections or stations discussed in text are labeled in italics along the top line. 


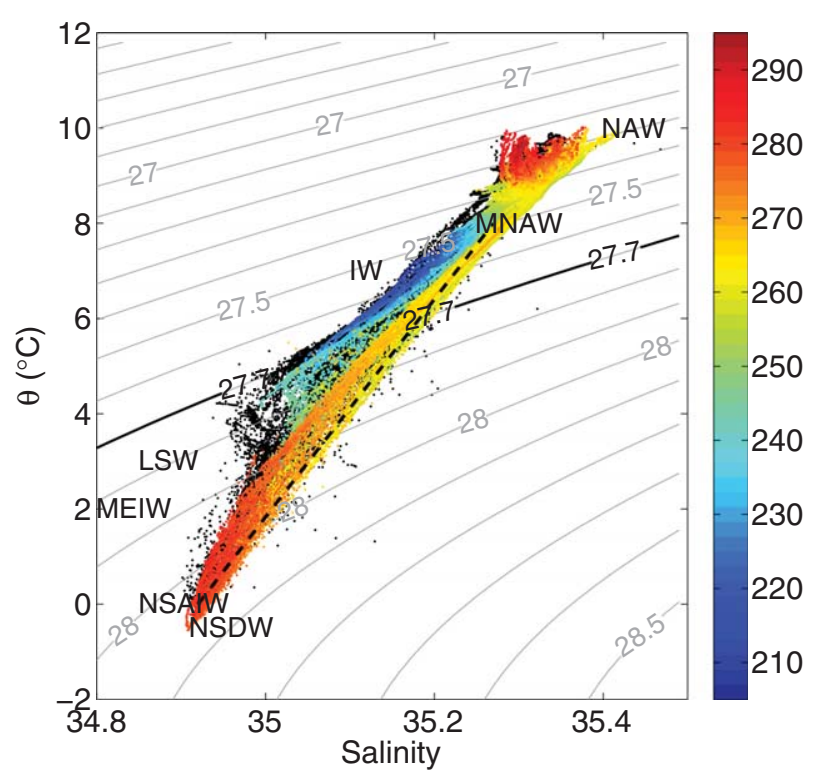

Figure 4. $\theta-S$ diagram, 1 dbar bin averaged data from glider Snotra (black) and CTD data, color coded by oxygen concentration $\left(\mu \mathrm{mol} \mathrm{kg}{ }^{-1}\right)$. Gray lines are $\sigma_{\theta}$ isopycnals at $0.1 \mathrm{~kg} \mathrm{~m}^{-3}$ intervals. Water masses labeled are: North Atlantic Water (NAW), Modified North Atlantic Water (MNAW), Intermediate Water (IW), Labrador Sea Water (LSW), Modified East Icelandic Water (MEIW), Norwegian Sea Arctic Intermediate Water (NSAIW), and Norwegian Sea Deep Water (NSDW). The black dashed line represents the mixing line referred to in text as the MNAW-NSDW line.

average) oxygen saturation to $100 \%$, as in Perry et al. [2008].

\section{Water Mass Characteristics}

\subsection{Temperature-Salinity Curves and Spiciness}

[21] At the time of the cruise, the hydrography of the FBC outflow region was dominated by warm and saline Atlantic waters in the upper layer and cold, fresh NSDW at depth, with a few of the deepest profiles showing the characteristics of NSAIW, i.e., a salinity minimum (or inflection point) at about $0^{\circ} \mathrm{C}$. Most of the survey data fell along a line in $\theta-S$ space ("linear" profiles) connecting the Atlantic water and NSDW end points (Figure 4). Some profiles, however, displayed a distinct influence of less saline intermediate waters ("curved" profiles). The intermediate water signature varied from a gentle curvature [referred to as "convexity" by Borenäs et al., 2001] or inflection point to a pronounced bump in the $\theta-S$ curve (cf. Figure 13), centered at about $\sigma_{\theta}=27.70 \mathrm{~kg} \mathrm{~m}^{-3}$. Some profiles fell on the MNAW-NSDW mixing line in part of the water column, but at some level displayed an abrupt transition to a less saline water mass. These "intrusion" type of profiles generally had salinity anomalies similar to the typical curved profiles, but unlike these, their $\theta-S$ traces were not dominated by the low-salinity curvature at all levels below the MNAW (see also section 3.3.1.).

[22] As a measure of the difference between "curved" and "linear" profiles, we define a density-compensated salinity anomaly $\Delta S$-sometimes called spiciness anomaly [Jackett and McDougall, 1985; Flament, 2002]-relative to the line between NSDW $\left(S=34.92, \theta=0^{\circ} \mathrm{C}\right)$ and MNAW $\left(S=35.27, \theta=8^{\circ} \mathrm{C}\right)$. That is, for each observation $\theta_{o}, S_{o}, \rho_{o}$ we find the salinity $S_{m}$ at the point where the relevant isopycnal $\rho_{o}$ intersects the mixing line between NSDW and MNAW, and define $\Delta S=S_{o}-S_{m}$. The most anomalous $\Delta S$ values $(<-0.15)$ were generally found in the density range $27.65<\sigma_{\theta}<27.75 \mathrm{~kg} \mathrm{~m}^{-3}$.

\subsection{Spatial Distribution}

[23] The $\theta-S$ profiles differed not only in strength of the isopycnal salinity anomaly but also qualitatively. "Linear" or "gently curved" profiles were most common in the eastern part of the study area (at section A, see Figure 2) or along the plume path (section B). Profiles with a marked negative salinity anomaly were found in the western part of the study area, mainly on section $\mathrm{C}$, west of about $9^{\circ} 20^{\prime} \mathrm{W}$. Although the relatively fresh water mass was commonly found in this region, its distribution was patchy and suggested strong time variability, as profiles from the same location showed presence or absence of this water mass at different times (Figure 5) - not only from one survey to the next but also during the 2012 cruise alone.

[24] A subsurface oxygen concentration minimum was generally found near the $\theta=7^{\circ} \mathrm{C}$ isotherm. The oxygen minimum was often much more marked-down to 206 $\mu \mathrm{mol} \mathrm{kg}-1$ - in the western profiles that contained the lowsalinity intermediate water signal than in the eastern, straight profiles, where oxygen concentrations were seldom lower than $250 \mu \mathrm{mol} \mathrm{kg}^{-1}$ (Figure 4).

[25] The salinity and oxygen anomalies generally cooccurred, in the sense that they were observed at the same stations (cf. Figures 5 and 6). The extrema, however, were

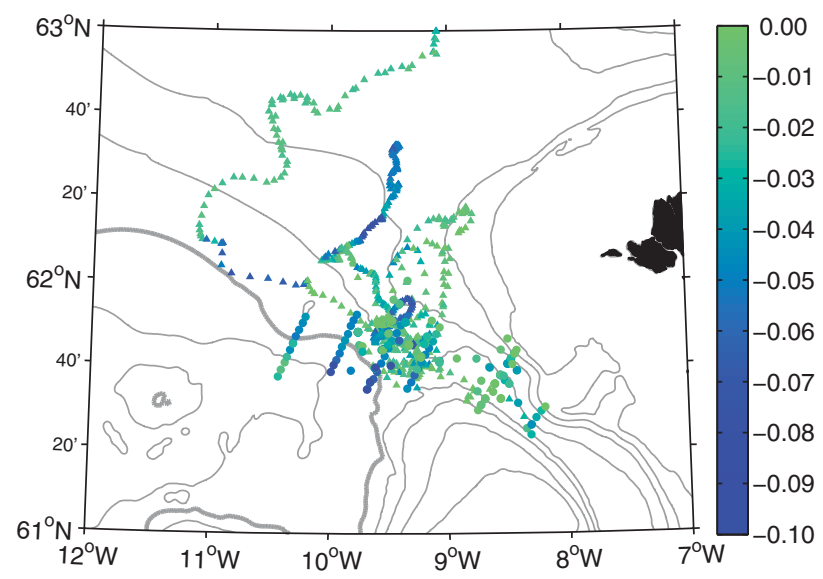

Figure 5. Spatial distribution of the isopycnal salinity anomaly relative to the straight line between $S=34.92$, $\theta=0^{\circ} \mathrm{C}(\sim \mathrm{NSDW})$, and $S=35.27, \theta=8^{\circ} \mathrm{C}(\sim \mathrm{MNAW})$, averaged over the range $0^{\circ} \mathrm{C}<8^{\circ} \mathrm{C}$. CTD profiles from the 2008 and 2012 cruises are marked as circles, glider profiles (Seaglider 2008 and Slocum 2012) as triangles. Salinity anomaly scale on the right; strong negative anomalies (blue colors) mean $\theta-S$ profiles deviate strongly from the MNAW-NSDW line, while "linear" profiles are red. Bathymetry is shown as thin gray contours at $200 \mathrm{~m}$ intervals; the bold gray line is the $1000 \mathrm{~m}$ contour. 


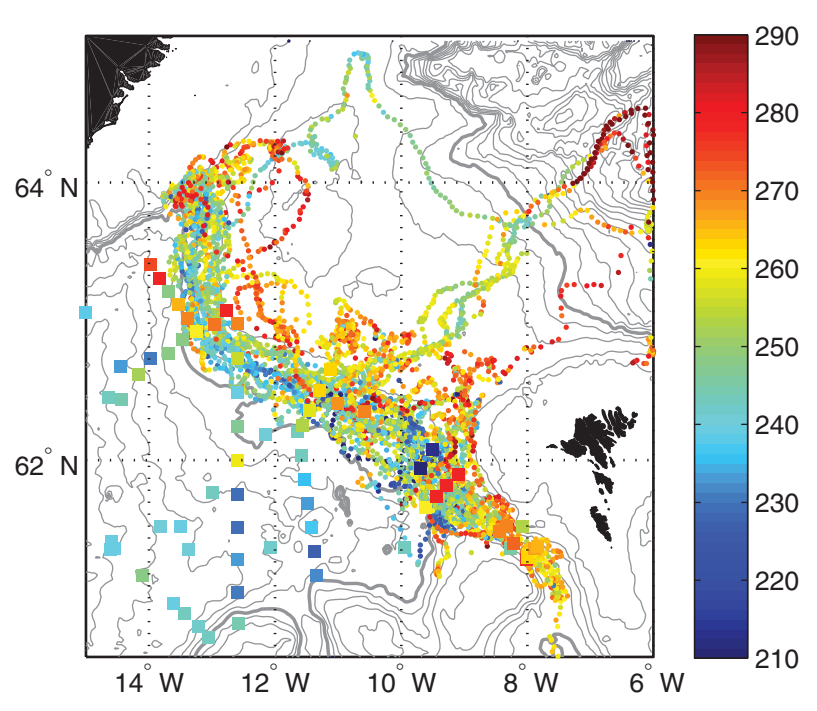

Figure 6. Spatial distribution of minimum oxygen concentration in the density range $27.45<\sigma_{\theta}<27.7 \mathrm{~kg} \mathrm{~m}^{-3}$ from World Ocean Database (squares) and Seagliders (dots). No oxygen data were measured with the Slocum gliders in 2012. Bathymetry as thin gray contours at $200 \mathrm{~m}$ intervals; $1000 \mathrm{~m}$ contour bold.

centered at different isopycnals, with the strongest $\mathrm{O}_{2}$ minima found at lighter densities than the salinity anomaly. The strongest influence of low-salinity water was always found together with a distinct $\mathrm{O}_{2}$ minimum, but among profiles with a medium or weak $\Delta S, \mathrm{O}_{2}$ minimum concentrations varied over a large range. The correlation coefficient of $\mathrm{O}_{2}$ minimum concentration with depth-averaged $\Delta S$ for the 2012 measurements (cf. Figure 7) was 0.57 , statistically significant at the 0.05 level ( $p$ value $<0.001)$.

[26] The oxygen concentration measured by a Seaglider that crossed the IFR in December 2007 [Beaird et al., 2013] showed a thick wedge of low-oxygen intermediate water taking up a large part of the water column at the southern end of the section, thinning northward (Figure 8). Results from several years of Seaglider surveys showed that oxygen minima below $240 \mu \mathrm{mol} \mathrm{kg}^{-1}$ in the density range $27.45<\sigma_{\theta}<27.7 \mathrm{~kg} \mathrm{~m}^{-3}$, taken as an indicator of IW presence, were found along the southern side of the IFR from the FBC exit to the Iceland shelf (Figure 6). The spatial distribution of oxygen minimum concentration within this region was patchy, however.

[27] In cruise data from 2008, the spatial distribution of the different types of hydrographic structure was more distinct - perhaps less confounded by time variability, as there was less repetition of stations or sections. Gently curved $\theta$ $-S$ traces were the most common on the sections closest to the sill, with the low salinity intermediate water signal prevalent on the sections west of $9^{\circ} \mathrm{W}$. In most cases this signal, where present, clearly dominated the profile, but occasionally it appeared as merely an intrusion in a profile following the MNAW-NSDW line. The low-salinity $\theta-S$ signal was generally weaker than in 2012; fewer stations in 2008 had a strong low-salinity anomaly, but the $\mathrm{O}_{2}$ minima were clearly marked (Figure 6). The low $\mathrm{O}_{2}$ minimum concentrations were linked with low depth-averaged $\Delta S$ values (Figure 7), with a correlation coefficient of 0.72 , statisti- cally significant at the 0.05 level ( $p$ value $<0.001$ ). Differences in water mass distribution between 2008 and 2012, aside from differences in station coverage, appeared small in relation to the large variability on short time and spatial scales observed in particular during the 2012 cruise.

[28] The water mass distribution as manifested in the shape of the $\theta-S$ curve was influenced by the presence of the dense overflow plume and the proximity to the sill. The less curved $\theta-S$ profiles dominated close to the sill, where the plume was thick, but were also found farther down the path of the thinning plume. The total thickness of the plume, $H_{p l}$, estimated as the depth of the $\sigma_{\theta}=27.65 \mathrm{~kg} \mathrm{~m}^{-3}$ isopycnal [Mauritzen et al., 2005] was $157 \pm 76 \mathrm{~m}$ (survey average). Near the sill, at section $\mathrm{A}$, the plume was about twice as thick $(317 \mathrm{~m})$. The boundary layer (BL) thickness of the overflow plume was defined, following Fer et al. [2010], as the height above bottom where the density first decreased from the deepest value by $0.01 \mathrm{~kg} \mathrm{~m}^{-3}$. The thickness of the interfacial layer (IL) was obtained as the vertical distance between the top of the BL and the first depth above it where $\delta \sigma_{\theta} / \delta z<5 \times 10^{-4} \mathrm{~kg} \mathrm{~m}^{-4}$. Both the BL and IL were thicker at section $\mathrm{A}$, where the $\mathrm{BL}$ at its thickest point was $159 \pm 30$ $\mathrm{m}$ and the IL on average $135 \pm 20 \mathrm{~m}$, than at the downstream section $\mathrm{C}$ where the plume thickness was also more variable or patchy, with BL thickness of $68 \pm 42 \mathrm{~m}$ and mean IL thickness of $91 \pm 43 \mathrm{~m}$. The along-path reduction in layer height is a result of entrainment of warmer waters, which leads to smaller amounts of overflow water fulfilling the criteria for the BL and IL, respectively.

\subsection{Temporal Variation}

\subsubsection{Time Series t1}

[29] Repeated CTD-LADCP profiles, 11 casts during $10 \mathrm{~h}$, performed at station t1 (Figure 2) on 29-30 May,

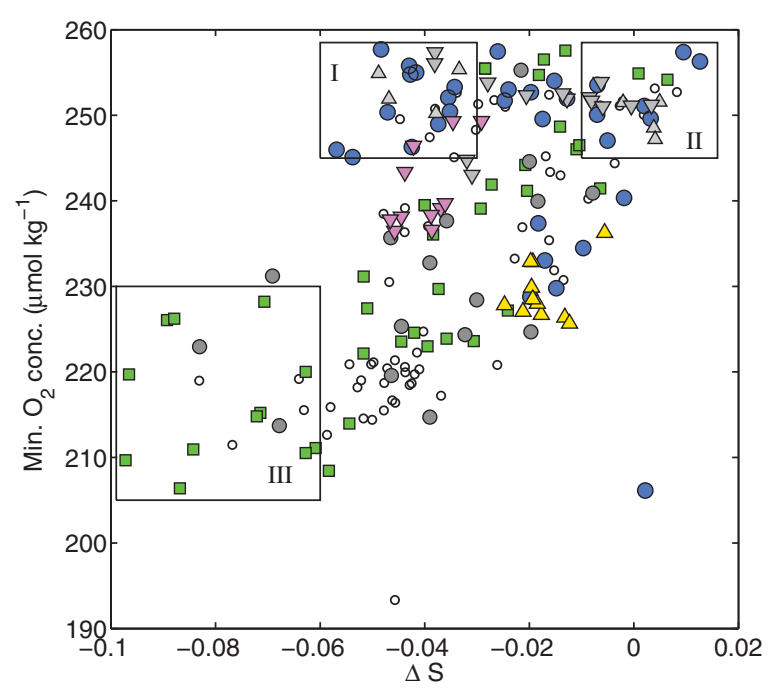

Figure 7. Minimum oxygen concentration $\left(\mu \mathrm{mol} \mathrm{kg}{ }^{-1}\right)$ plotted against depth-averaged spiciness anomaly, $\Delta S$. Cruise data from 2012 are represented by filled markers (the symbols for different stations correspond to those in Figure 2), data from 2008 by open markers. Profiles are classified based on this diagram. Boxes demark the property boundaries of the profile groups States I, II, and III, also shown in Figure 12. 


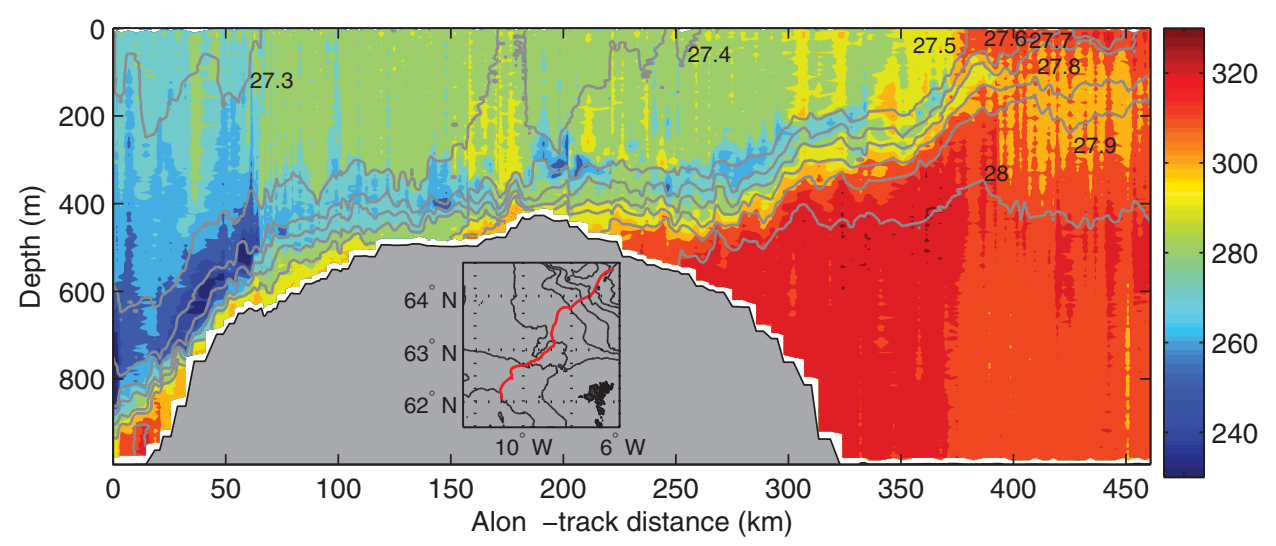

Figure 8. Section of oxygen concentration across the IFR measured by a Seaglider that occupied the line (shown inset map) 2-23 December 2007. Isopycnals are drawn in gray; contour interval is $0.1 \mathrm{~kg}$ $\mathrm{m}^{-3}$. The horizontal axis shows, from left to right, the distance from the south-west end point of the track toward the north-east.

highlighted the complex vertical structure and temporal variability of the water masses at the exit of the FBC. During the $10 \mathrm{~h}$ of measurements, the maximum along-stream (northwesterly) plume velocity increased from $61 \mathrm{~cm} \mathrm{~s}^{-1}$ to at most $86 \mathrm{~cm} \mathrm{~s}^{-1}$. The well-mixed BL gradually cooled (from $1.8^{\circ} \mathrm{C}$ in the first profile to a minimum of $0.9^{\circ} \mathrm{C}$ ) and became denser, accompanied by an increase in $\mathrm{O}_{2}$ concentration. While the water mass properties became more markedly "plume like," the thickness of the BL ( 60 m) remained unchanged.

[30] Two tongues of relatively low-salinity, low-oxygen water appeared at station $\mathrm{t} 1$, one in the $\mathrm{IL}\left(3<\theta<6^{\circ} \mathrm{C}\right)$ and one in the Atlantic water layer $\left(\theta>8^{\circ} \mathrm{C}\right.$; see Figure $9 \mathrm{a})$, separated by a layer of typical MNAW-NSDW mixture with higher $\mathrm{O}_{2}$ concentration. In the first cast, two zones of low $\mathrm{O}_{2}$ concentration $\left(\sim 250 \mu \mathrm{mol} \mathrm{kg} \mathrm{kg}^{-1}\right)$ were already

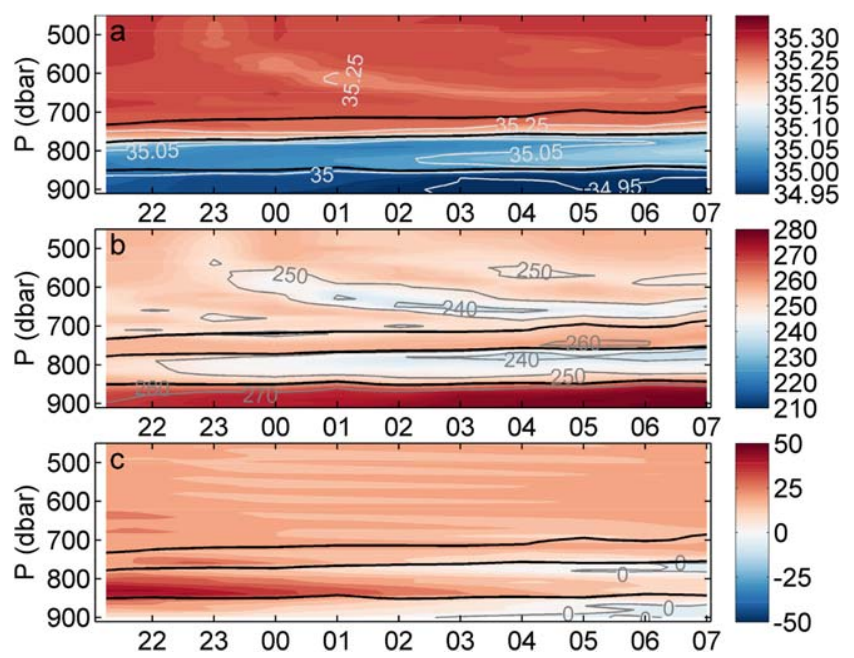

Figure 9. Time series station t1, contour plots of (a) salinity, (b) $\mathrm{O}_{2}$ concentration $\left(\mu \mathrm{mol} \mathrm{kg} \mathrm{kg}^{-1}\right.$ ), and (c) "cross-plume" velocity $\left(\mathrm{cm} \mathrm{s}^{-1}\right)$, the component directed to the right of the direction of the velocity maximum, shown in color (scale on the right) and with labeled gray contours. Bold black lines mark the $3^{\circ}, 6^{\circ}$, and $8^{\circ} \mathrm{C}$ isotherms. apparent: a deep $\mathrm{O}_{2}$ minimum centered at $\sigma_{\theta}=27.80$ $\mathrm{kg} \mathrm{m}^{-3}$, and an upper one with double peaks at $\sigma_{\theta}=27.45$ and $27.48 \mathrm{~kg} \mathrm{~m}^{-3}$ (Figure 9a).

[31] The deeper (IL) low-oxygen layer was associated with a spiciness anomaly, initially apparent only as a gentle curvature of the $\theta-S$ profiles. During the following hours, the low salinity intrusion grew in magnitude, forming a distinct "bulge" in the $\theta-S$, while the $\mathrm{O}_{2}$ minimum concentration decreased (Figure 9b). The strongest $\Delta S(<-0.15$, corresponding to $S=35.02$ ) occurred in the cast collected at $02: 00$. Thereafter, salinities gradually increased and the spiciness anomaly layer thinned, but the $\mathrm{O}_{2}$ minimum remained thick and strong, with the lowest $\mathrm{O}_{2}$ concentration of $237 \mu \mathrm{mol} \mathrm{kg}{ }^{-1}$ found in the last cast. The lowsalinity, low-oxygen tongue became gradually lighter, so that in the end of the $10 \mathrm{~h}$ time series its core was closer to $\sigma_{\theta} \sim 27.70$ than $27.80 \mathrm{~kg} \mathrm{~m}^{-3}$. A small local velocity maximum at the top of the IL shifted upward by some $40 \mathrm{~m}$ and veered from northerly to northwesterly and thus became aligned with the main plume velocity core.

[32] The upper low-oxygen layer showed typical MNAW properties in the beginning of the time series. However, a strengthening of the $\mathrm{O}_{2}$ minimum was accompanied by a moderate decrease in both salinity and temperature. This cool, fresh, low-oxygen feature was constrained to a narrow density range of about $27.43<\sigma_{\theta}<27.50 \mathrm{~kg}$ $\mathrm{m}^{-3}$, corresponding to the pressure range 500-700 dbar in the weakly stratified Atlantic water layer. The strongest $\mathrm{O}_{2}$ minimum $\left(238 \mu \mathrm{mol} \mathrm{kg}^{-1}\right)$ in this upper tongue was found at 660 dbar. As the temperature decreased in both the Atlantic layer and the BL but increased in the IL, two marked thermoclines developed. The velocity profile also showed a "two-core" structure (Figure 9c).

\subsubsection{Repeat Slope Section $\mathrm{C}$}

[33] The hydrographic section $\mathrm{C}$, about $50 \mathrm{~km}$ downstream from the sill crest, was occupied five times between 1 and 4 June 2012, starting about $15 \mathrm{~h}$ apart and taking about $9 \mathrm{~h}$ to complete. The dense plume, containing NSDW, was present during all five occupations of the section, while the upper layer was always taken up by MNAW. A low salinity anomaly could be seen at 

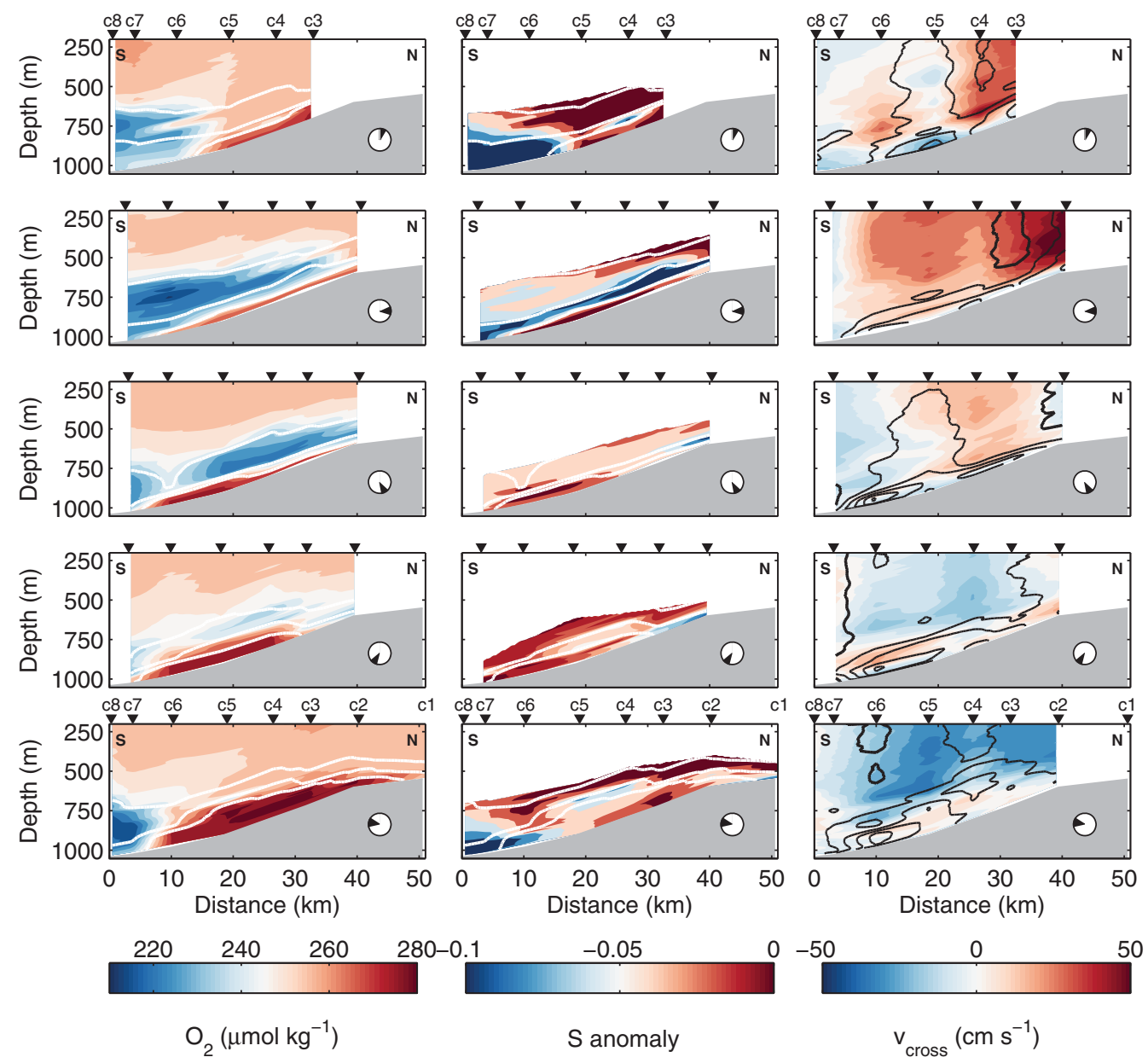

Figure 10. Oxygen concentration, isopycnal salinity anomaly relative to the MNAW-NSDW mixing line, and cross-stream current velocity at section $\mathrm{C}$ for each of the repeated sections (1 June 12-19, 2 June 03-13, 2 June 19-03, 3 June 09-17, and 4 June 00-10), plotted with bottom-following interpolation. Faroe Bank is on the left and Faroe Plateau on the right-hand side; southern $(\mathrm{S})$ and northern $(\mathrm{N})$ end of section labeled. Only depths $>200 \mathrm{~m}$ shown; the salinity anomaly is defined only in the $0^{\circ}<\theta<8^{\circ} \mathrm{C}$ range. Bold white contours in columns 1 and 2 mark the $3^{\circ}, 6^{\circ}$, and $8^{\circ} \mathrm{C}$ isotherms. Along-stream velocity contours, at $25 \mathrm{~cm} \mathrm{~s}^{-1}$ intervals, are overlaid in black in column 3 ; the zero contour is bold. The time during which each section was occupied is shown in the "clock" diagram, in which a full turn corresponds to a characteristic mesoscale period of 3.5 days, on the lower right in each plot.

intermediate levels above the plume and beneath the Atlantic water (Figure 10). The deviation from the MNAWNSDW mixing line was strongest in the IL, approximately delimited by the $3^{\circ} \mathrm{C}$ and $6^{\circ} \mathrm{C}$ isotherms, but noticeable up to about the $8^{\circ} \mathrm{C}$ isotherm, or $\sim 400 \mathrm{~m}$ above the seabed. During the first visit, the low-salinity signal was stronger than in the following occupations and found in a thicker layer, taking up the bottommost $200 \mathrm{~m}$ at the deepest stations. During the later visits, the low-salinity signal was weaker, spread out in a thinner interfacial layer, separated from the bottom, and stretching across the whole section. On the last visit, a wedge of stronger negative salinity anomaly recurred at the deepest stations.

[34] Oxygen concentrations were always high in the overflow plume. Above the plume, a wedge of low-oxygen water was found, usually with minimum concentrations $<240 \mu \mathrm{mol} \mathrm{kg}{ }^{-1}$. The oxygen minimum was above the IL, centered between the $6^{\circ} \mathrm{C}$ and $8^{\circ} \mathrm{C}$ isotherms. The low- oxygen water mass was also colder than the water it replaces laterally, manifested in the upward bulging of the $8^{\circ} \mathrm{C}$ isotherm and thickening of the $6<\theta<8^{\circ} \mathrm{C}$ layer whenever the strong oxygen minimum was present. During the first visit of section $\mathrm{C}$, a strong oxygen minimum was found at the southernmost stations, above the low-salinity "blob" or wedge, but later it spread northeastward across almost the whole section. Just as with the low-salinity signal, a renewed, stronger pulse of low oxygen concentration appeared at the deep end of the section during the last visit, but unlike the salinity, the oxygen minimum in the $6<\theta<8^{\circ} \mathrm{C}$ layer was more marked in the later pulse. The low-salinity, low-oxygen water present during the last visit of section $\mathrm{C}$ thus appeared to be different from the feature encountered during the first visit.

[35] Velocities were rotated with respect to the maximum plume velocity (defined as the maximum velocity in the bottommost $300 \mathrm{~m}$ ) at each station into an along-plume and an 

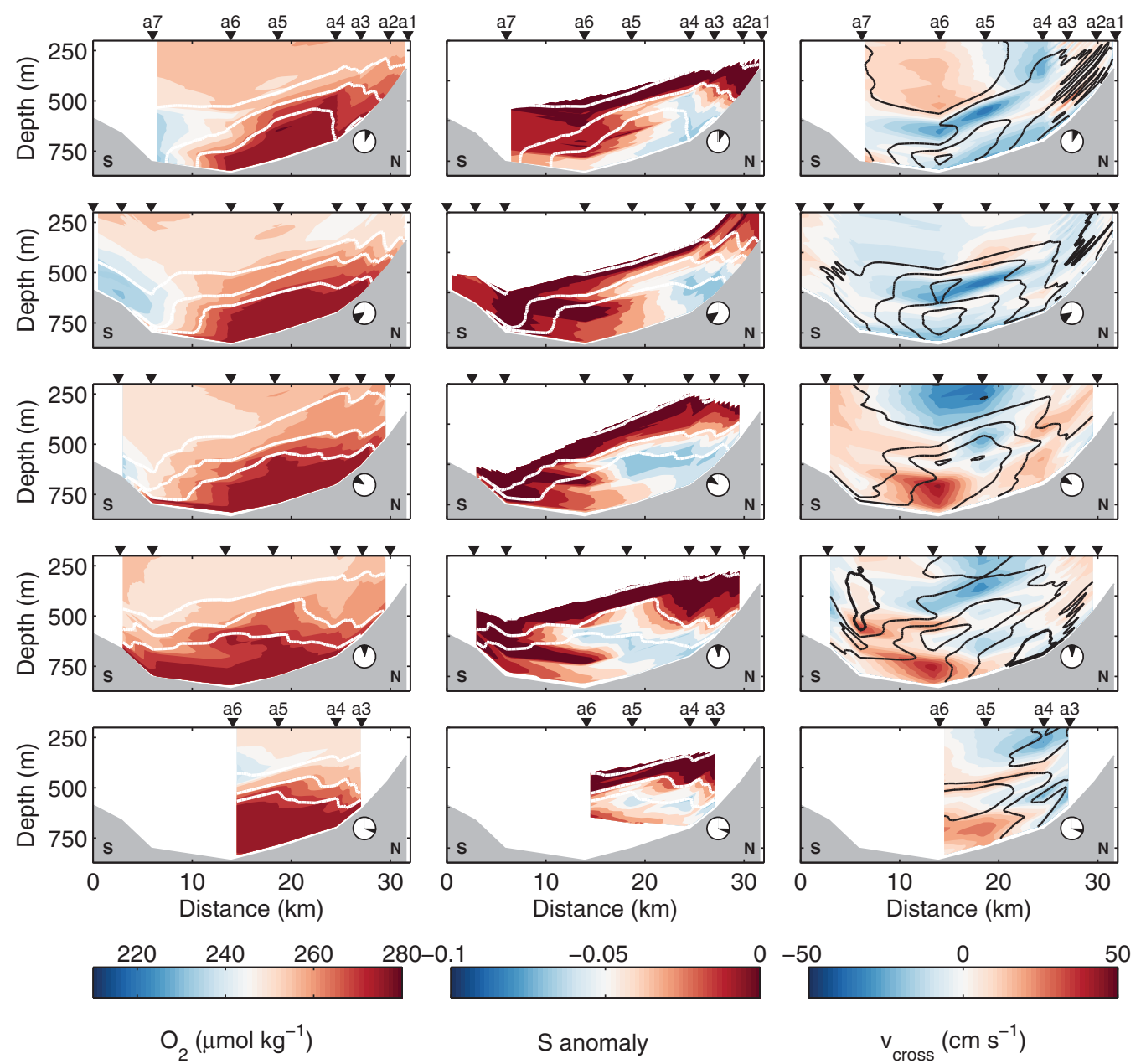

Figure 11. Repeated hydrographic section A; as Figure 10. Note: there was a gap of over a week between the first (31 May), and subsequent occupations (9-12 June).

across-plume flow component. During all five occupations of section $\mathrm{C}$, the direction of the maximum plume velocity was west-northwest, $283 \pm 12^{\circ}$. The events with the strongest oxygen-minimum blob coincided with a weaker or even negative along-plume flow above and southwest of the plume core, but the minimum in along-plume current did not always correspond exactly to the location of the strongest oxygen minimum (Figure 10). The strongest water mass anomalies were found when flow in the water column above the $\mathrm{BL}$ was positive (to the right, i.e., northward), but again, the cross-stream velocity maximum did not coincide with the maximum hydrographic anomaly.

[36] In all depth layers, there was a tendency for progressive vectors to curve, seen as a reversal of the cross-stream flow component in Figure 10 (right-hand column) from the first to the last occupation. The net cross-stream transport per unit width was on average southward in the BL and roughly equal but opposite in the thicker IL $\left(-1.4 \mathrm{~m}^{2} \mathrm{~s}^{-1}\right.$ and $1.6 \mathrm{~m}^{2} \mathrm{~s}^{-1}$, respectively, at station $\mathrm{c} 5$ ). At the stations on the deeper side of the slope (southward of station c5; deeper than $900 \mathrm{~m}$ ), the net displacement in the upper layer during the $>2.5$ days of measurement was to the north-northeast whereas at the stations further up on the slope, the net upper layer displacement was larger $(\sim 48 \mathrm{~km}$ at station c4, compared to $\sim 24 \mathrm{~km}$ at $\mathrm{c} 6$ ) and to the eastnortheast.

\subsubsection{Repeat Channel Section A}

[37] Section A near the FBC sill at about $8^{\circ} 30^{\prime} \mathrm{W}$ was first occupied starting on 31 May, and repeated four times about a week later (Figure 11). As expected, the overflow plume was thicker and velocities higher in this narrow section than at section $\mathrm{C}$ further west. At times, in particular during the last two visits, there was evidence of isopycnals being "pinched," i.e., closer together, on the Faroe Bank (the southern) side of the section and spread out on the Faroe Islands side. There was always a deviation from the MNAW-NSDW line of as much as $\Delta S \sim-0.09$ on the northern side. Weaker than at section $\mathrm{C}$, this salinity anomaly centered roughly on the $3^{\circ} \mathrm{C}$ isotherm corresponded to the gently curved type of $\theta-S$ profiles, and was not accompanied by an oxygen minimum. Slightly lower oxygen concentrations were found on the southern side of the section, with anomalies relatively weaker than at the downstream section.

[38] The maximum plume velocity was always strongest at the deepest station, a6 (Figure 11), and directed toward northwest, $304 \pm 26^{\circ}$. The cross-stream velocity pattern was complex, with several flow reversals between different thin 

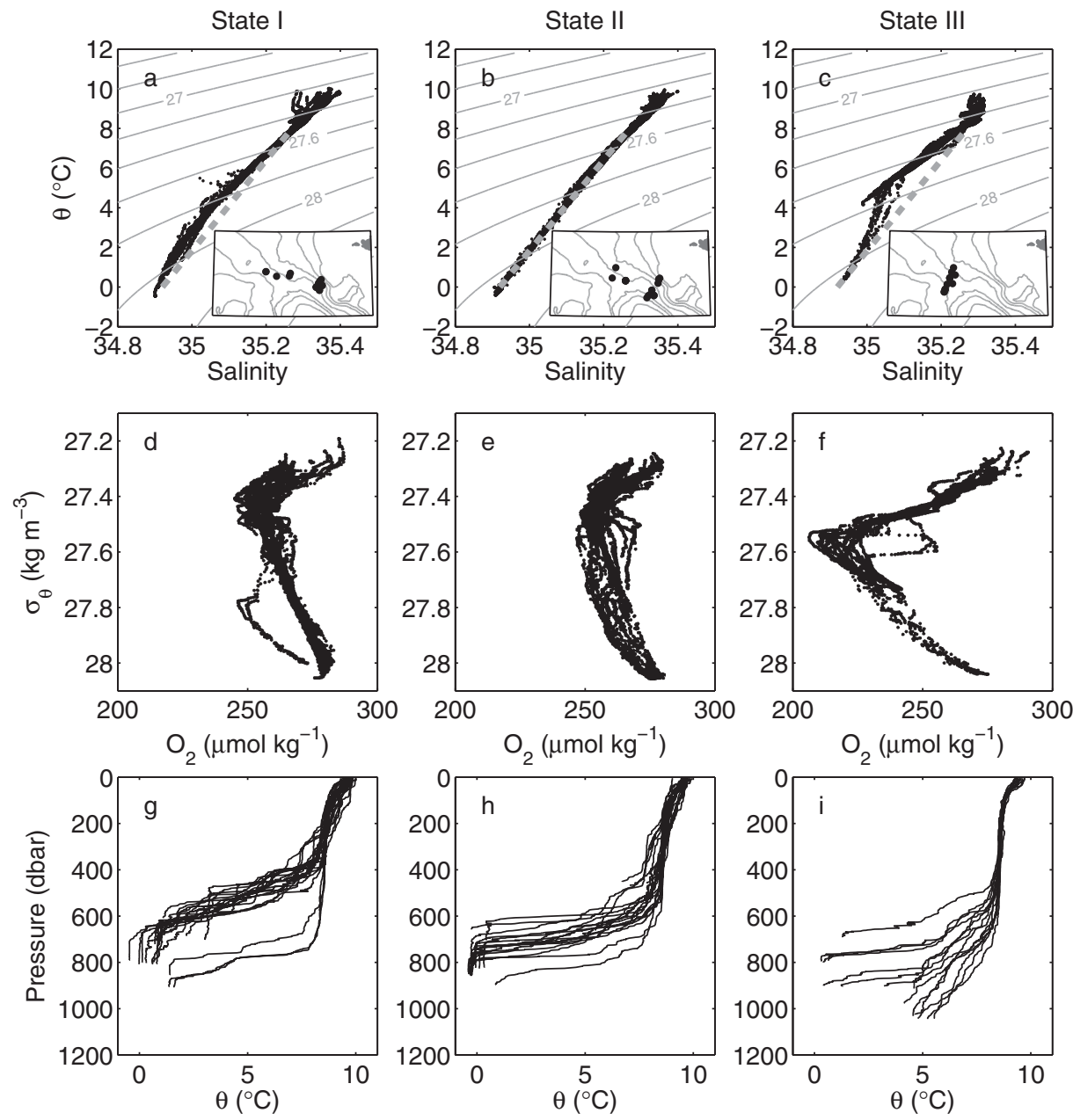

Figure 12. Groups of CTD profiles from the 2012 cruise classified as (left column) State I, (middle column) II, and (right-hand column) III based on their $\theta-S$ and oxygen properties (cf. Figure 7). (a) The gently curved State I $\theta-S$ profiles (d) usually displayed weak oxygen minima and (g) were usually found in the overflow plume; (b) State II differed from these mainly in terms of their linear $\theta-S$ relationship (e) but were similar in oxygen values and (h) other plume properties. In contrast, (c) State III profiles with a strong low-salinity signal at the intermediate level (f) had strong oxygen minima and (i) were more common where there was a thin or no plume (i).

layers. During the first two occupations of the section, when the along-stream velocity had a strong maximum in the BL, the cross-stream flow component in the BL was negative (southward) while in the IL above it, the cross-stream velocity was zero or even weakly positive in a thin layer. In contrast, during later visits there was a relatively strong positive (northward) cross-stream flow within the BL.

\section{Discussion}

[39] Following Borenäs et al. [2001], we classified $\theta-S$ profiles curved toward lower intermediate salinities as "State I" and linear profiles as "State II" (see Figure 12 and the schematic Figure 13). State I profiles contain a portion of MEIW, strongly diluted after having mixed with surrounding waters along its clockwise route around the Faroe Islands, through the FSC and then the FBC. The mixing is reflected in the smooth $\theta-S$ curvature of these profiles, that display a weak convexity over large parts of the water column, with the salinity difference compared to the MNAW-NSDW line largest between about $2^{\circ} \mathrm{C}$ and $4^{\circ} \mathrm{C}$, and roughly equally strong throughout this range (about 0.05). The main difference between State I and State II profiles is that State I profiles are less saline than State II at intermediate levels (below ca. 500-600 m). Together these types of profiles dominate the sections near the sill. If the water column upstream, in the FSC, contains a clear MEIW signal the result of the mixing it undergoes in the Faroese Channels is a State I $\theta-S$ profile. If MEIW is not present, and Atlantic water is found directly on top of NSDW, a State II $\theta-S$ line is produced. The latter case is more common on the southern side of the channel, where isopycnals are pinched together, whereas MEIW is typically present on the northern side, as demonstrated in Figure 13. The State I and II profiles have thus all been subject to strong mixing, and the (slight) $\theta-S$ difference between them only reflects whether there was a MEIW signal or not beforehand. Since MEIW is not marked by any specific oxygen 


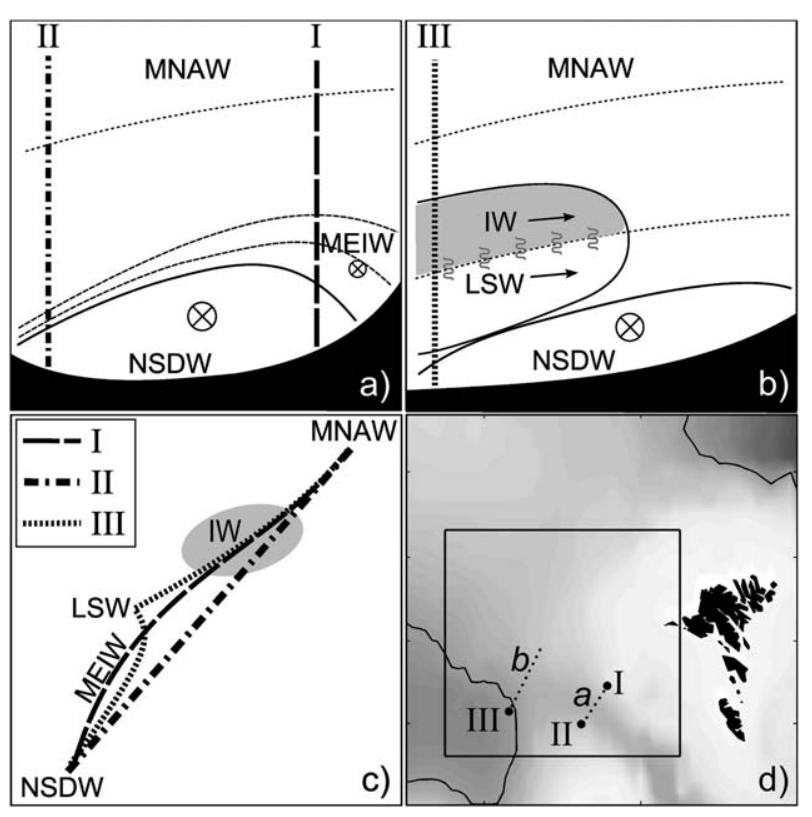

Figure 13. (a) Schematic representation of a crosssection downstream of the sill in the FBC (labeled "a" in the map shown in Figure 13d). Looking downstream in the direction of the thick plume the section shows the situation of two "CTD profiles," where the right-hand side (northern) one, I, marked by a dashed line, is represented by I in the map (d) and the dashed line in the " $\theta-S$ " diagram in Figure 13c. The left hand, southern, profile (dashdotted line) corresponds to II in the map and the dashdotted " $\theta-S$ " curve. (b) Cross-section further out on the slope to the west, labeled " $b$ " in the map; the profile (III, dotted line) is labeled III in the map and corresponds to the dotted " $\theta-S$ " curve. (c) Schematic diagram demonstrating the characteristic traces in " $\theta-S$ " space (" $S$ " on the horizontal and " $\theta$ " on the vertical axis) resulting from the water column structures shown in sections $a$ and $b$, and referred to in text as State I, II, and III (see legend). The gray shading symbolizes that IW, the upper of the intermediate water masses entering our study region from the Iceland Basin (cf. Figure 13b) is not marked by $\theta-S$ but rather by oxygen characteristics. For reference, the area of Figure $1 \mathrm{~b}$ is delineated in Figure 13d.

signal, there is no difference between State I and State II in terms of oxygen concentration (see Figures 7 and 12). Linear $\theta-S$ profiles are not found in the FSC [Hansen and Østerhus, 2007] and are therefore doubtless linked to local mixing in the FBC.

[40] In our measurements, that cover the outflow region farther west than those of Borenäs et al. [2001], we propose a "State III." Hydrographic properties for each categorized state are presented in Figure 12 separately. The State III hydrographic profiles, found west of $9^{\circ} \mathrm{W}$ in 2012, showed a distinctive low-salinity signal, not only stronger than the State I anomaly in magnitude but also found at higher temperatures $\left(4-5.5^{\circ} \mathrm{C}\right)$ and markedly different in shape: they contain a proper local minimum, clearly less eroded in character (see Figure 13). We conclude that these strong salinity minima mark the recent influence of another water mass. Since these profiles most commonly occur in the southwestern part of our study region we associate this water mass with the Iceland Basin. We speculate that this water mass is a derivative of LSW mixed with overlying lighter waters. Although the main LSW core is found at deeper depths in the central Iceland Basin, LSW is expected to mix with overflow waters from the FBC and south of the IFR [Talley and McCartney, 1982].

[41] The strong oxygen minimum observed at many western stations is a typical signature of IW, but this water mass is not associated with any distinct $\theta-S$ characteristic. The marked low-salinity signal, while often appearing in the same CTD cast as the low-oxygen water mass, was centered at deeper density levels. The water mass with the strong oxygen minimum can uncontroversially be labeled IW, but this does not explain the often geographically colocated but deeper low-salinity signal. We hypothesize that the low-salinity intermediate water mass we observe is a mixing product of IW with the underlying LSW found in the Iceland Basin (Figure 13b). However, we cannot rule out, based on $\theta-S$ properties alone, that the low salinity signal - in particular in the cases of low salinities found in glider data from the northern part of our study region, on the slope of the IFR (Figure 5) - could be derived from MEIW (Figure 4) overflowing the IFR. There is little direct evidence in literature for such overflows; they are inferred more than observed. Data from Seagliders crossing the IFR do indicate a thin layer of low-salinity water crossing the IFR [Beaird et al., 2013]. However, the lowest oxygen concentrations in the Seaglider data set occurred on the southwestern side of the IFR and not in the waters crossing it from the northeast (Figure 6).

[42] In most of the observations from the 2012 research cruise, the strongest low-salinity anomalies were accompanied by strong oxygen minima and were found in the southwestern part of our study region. This water therefore seems likely to be the result of upper LSW and IW blending in the northern Iceland Basin. In the central Iceland Basin, there is a pool of low-oxygen IW which is brought northward (west of Hatton Bank, see Figure 1a) by the general cyclonic circulation in the basin [Sarafanov et al., 2012]. The IW found in the IFR region is close to the northern limit of this water mass, which in part explains its patchy lateral distribution (Figure 6) and variable vertical extent. Our observations of low-salinity and low-oxygen waters from the Iceland Basin intruding between MNAW and NSDW as far east as $9^{\circ} 30^{\prime} \mathrm{W}$ challenge the assumption of van Aken and de Boer [1995] that IW does not contribute significantly to the modification of the overflow waters. A mixture of IW and LSW interacts with the FBC overflow waters already at a relatively short distance from the sill, and can be traced all the way to the IFR. Interannual changes in the extent of IW in this region are expected, however, and likely linked to the strength of the subpolar gyre circulation [Hátún et al., 2005].

[43] The fine structure in the State III $\theta-S$ profiles at the exit of the FBC is characteristic for regions dominated by eddy stirring, which acts to increase $\theta-S$ gradients, in contrast to the smooth $\theta-S$ profiles near the sill, typical of turbulence dominated regions [Ferrari and Polzin, 2005]. During the period that the hydrographic section at $9^{\circ} 30^{\prime} \mathrm{W}$ was repeated, a barotropic current, probably caused by topographic Rossby waves, was associated with a 
wave-pattern in sea surface height along the slope [Darelius et al., 2013]. The advection of cooler and loweroxygen water from the southern end of the section occurred on a time scale similar to the characteristic mesoscale oscillations of this area, suggesting that the waves play a role in stirring intermediate waters from the Iceland Basin into the plume region [Darelius et al., 2013].

[44] The interaction between intermediate water masses is highly variable on both tidal (Figure 9) and mesoscale (Figure 10) time scales. Variability with the period of M2 tides (presumably M2 internal waves) might act to move low-oxygen water in the water column with respect to the interfacial layer. Stirring by continental shelf waves and eddies, and by the secondary circulation modulated by eddies [Seim and Fer, 2011], can then export this water toward the Iceland-Faroe Front (Figure 8). The semidiurnal tidal excursion based on typical tidal velocities of $15 \mathrm{~cm} \mathrm{~s}^{-1}$ [Darelius et al., 2011] is $2 \mathrm{~km}$; for comparison, the lateral excursion estimated over a $12.5 \mathrm{~h}$ period based on average upper layer current velocity is about $12 \mathrm{~km}$. Internal waves at tidal frequencies have been observed in the FSC and at the slope of the Wyville-Thomson Ridge [e.g., Hosegood et al., 2005; Hall et al., 2011]. In the FBC, enhanced kinetic energy levels in the internal wave frequency band have been measured; mainly, however, at internal wave frequencies higher than semidiurnal [Seim and Fer, 2011]. Breaking of internal waves has been suggested as an important factor to explain the high levels of mixing in the FBC [Mauritzen et al., 2005].

[45] Previous estimates of overflow transport and entrainment rates inferred between sections across the channel may have suffered from including non-overflow water. The overflow water, consisting mainly of NSDW, has a high oxygen concentration (Figure 10) and is neatly delineated by the $3^{\circ} \mathrm{C}$ isotherm. If the interfacial layer, up to $6^{\circ} \mathrm{C}$, is considered in overflow estimates from cross sections downstream of the sill, the fresh, low-oxygen intermediate waters from the Iceland Basin are included although they are not part of the overflow.

\section{Summary}

[46] Measurements were made of hydrographic properties, oxygen content, and current velocity, during a research cruise to the Faroe Bank Channel outflow region in MayJune 2012. Our detailed in situ measurements have shown previously unreported interaction between FBC overflow waters and low-oxygen content water in the Iceland Basin and near the Iceland-Faroe Front. The low-oxygen water is found to be associated with a distinct negative $\theta-S$ anomaly that is, however, strongest at a higher density level than the oxygen minimum, reflecting the origin of this water as a mixture of IW and LSW. The low oxygen, low-salinity water is typically located between the $3^{\circ} \mathrm{C}$ and $8^{\circ} \mathrm{C}$ isotherms (Figure 10) in the stratified layer above the overflow core, where the secondary circulation in the interface [Seim and Fer, 2011] favors transport northward toward the IFR. Over the 3 day cycle in Figure 10 water with strong $\mathrm{O}_{2}$ minimum and $\Delta S$ crept into the interface above the $3^{\circ}$ isotherm and was transported northward along isopycnals. This process may continue all the way to the Iceland Faroe Front, aided by the large-scale eddy stirring. This is an intermittent — on eddy time scales - but robust process, observed in data from several years. The mesoscale variability at time scales of 3-5 days facilitates transport along the isopycnals $27.5<\sigma_{\theta}<27.9 \mathrm{~kg} \mathrm{~m}^{-3}$ that outcrop in the Norwegian Sea along the Iceland-Faroe Front (Figure 8).

[47] Acknowledgments. We thank the crew of the R. V. Håkon Mosby, and the technicians and students that were involved in the research cruise. The Matlab toolbox used for glider data post-processing was developed and kindly shared by Gerd Krahmann at GEOMAR, Kiel. The glider support team at Teledyne Webb Research are gratefully acknowledged. We thank Toby Sherwin and two anonymous reviewers for their comments and suggestions that helped improve the manuscript. This work was funded by the Research Council of Norway, through the FRINAT program, under the project 204867/V30, "Faroe Bank Channel Overflow: Dynamics and Mixing."

\section{References}

Beaird, N. L., I. Fer, P. Rhines, and C. Eriksen (2012), Dissipation of turbulent kinetic energy inferred from Seagliders: An application to the Eastern Nordic Seas overflows, J. Phys. Oceanogr., 42, 2268-2282.

Beaird, N. L., P. B. Rhines, and C. C. Eriksen (2013), Overflow waters at the Iceland-Faroe Ridge observed in multi-year Seaglider surveys, J. Phys. Oceanogr., 43, 2334-2351, doi:10.1175/JPO-D-13-029.1.

Blindheim, J. (1990), Arctic intermediate water in the Norwegian Sea, Deep Sea Res., Part A, 37, 1475-1489.

Borenäs, K., and P. Lundberg (2004), The Faroe-Bank Channel deep-water overflow, Deep Sea Res., Part II, 51, 335-350.

Borenäs, K. M., and P. A. Lundberg (1988), On the deep-water flow through the Faroe Bank Channel, J. Geophys. Res., 93(C2), 1281-1292.

Borenäs, K. M., I. M. Lake, and P. A. Lundberg (2001), On the intermediate water masses of the Faroe-Bank Channel overflow, J. Phys. Oceanogr., 31, 1904-1914.

Darelius, E., I. Fer, and D. Quadfasel (2011), Faroe Bank Channel overflow: Mesoscale variability, J. Phys. Oceanogr., 41, 2137-2154.

Darelius, E., J. E. Ullgren, and I. Fer (2013), Observations of barotropic oscillations and their influence on mixing in the Faroe Bank Channel overflow region, J. Phys. Oceanogr., 43, 1525-1532, doi:10.1175/JPOD-13-059.1.

Dooley, H. D., and J. Meincke (1981), Circulation and water masses in the Faroese Channels during Overflow '73, Deut. Hydrogr. Z., 34, 41-45.

Duncan, L. M., H. L. Bryden, and S. A. Cunningham (2003), Friction and mixing in the Faroe Bank Channel outflow, Oceanol. Acta, 26, 473-486.

Egbert, G. D., and S. Y. Erofeeva (2002), Efficient inverse modeling of barotropic ocean tides, J. Atmos. Oceanic Technol., 19, 183-204.

Egbert, G. D., S. Y. Erofeeva, and R. D. Ray (2010), Assimilation of altimetry data for nonlinear shallow-water tides: Quarter-diurnal tides of the Northwest European Shelf, Cont. Shelf Res., 30, 668-679.

Eriksen, C. C., T. J. Osse, R. D. Light, T. Wen, T. W. Lehman, P. L. Sabin, J. W. Ballard, and A. M. Chiodi (2001), Seaglider: A long-range autonomous underwater vehicle for oceanographic research, IEEE J. Oceanic Eng., 26(4), 424-436.

Fer, I., G. Voet, K. S. Seim, B. Rudels, and K. Latarius (2010), Intense mixing of the Faroe Bank Channel overflow, Geophys. Res. Lett., 37, L02604, doi:10.1029/2009GL041924.

Ferrari, R., and K. Polzin (2005), Finescale structure of the t-s relation in the eastern north Atlantic, J. Phys. Oceanogr., 35(8), 1437-1454.

Flament, P. (2002), A state variable for characterizing water masses and their diffusive stability: Spiciness, Prog. Oceanogr., 54, 493-501.

Fogelqvist, E., J. Blindheim, T. Tanhua, S. Østerhus, E. Buch, and F. Rey (2003), Greenland-Scotland overflow studied by hydro-chemical multivariate analysis, Deep Sea Res., Part I, 50, 73-102.

Garau, B., S. Ruiz, W. G. Zhang, A. Pascual, E. Heslop, J. Kerfoot, and J. Tintoré (2011), Thermal lag correction on Slocum CTD glider data, J. Atmos. Oceanic Technol., 28, 1065-1071.

Geyer, F., S. Østerhus, B. Hansen, and D. Quadfasel (2006), Observations of highly regular oscillations in the overflow plume downstream of the Faroe Bank Channel, J. Geophys. Res., 111, C12020, doi:10.1029/ 2006JC003693.

Hall, R. A., J. M. Huthnance, and R. G. Williams (2011), Internal tides, nonlinear internal wave trains, and mixing in the Faroe-Shetland Channel, J. Geophys. Res., 116, C03008, doi:10.1029/2010JC006213. 


\section{ULLGREN ET AL.: FAROE BANK CHANNEL INTERMEDIATE WATER}

Hansen, B., and S. Østerhus (2000), North Atlantic-Nordic Seas exchanges, Prog. Oceanogr., 45, 109-208.

Hansen, B., and S. Østerhus (2007), Faroe Bank Channel overflow 19952005, Prog. Oceanogr., 75, 817-856.

Hansen, B., W. R. Turrell, and S. Østerhus (2001), Decreasing overflow from the Nordic seas into the Atlantic Ocean through the Faroe Bank channel since 1950, Nature, 411, 927-930.

Hansen, B., S. Østerhus, D. Quadfasel, and W. Turrell (2004), Already the day after tomorrow?, Science, 305, 953-954.

Hátún, H., A. Sandø, H. Drange, B. Hansen, and H. Valdimarsson (2005), Influence of the Atlantic subpolar gyre on the thermohaline circulation, Science, 309(5742), 1841-1844

Hosegood, P., H. van Haren, and C. Veth (2005), Mixing within the interior of the Faeroe-Shetland Channel, J. Mar. Res., 63, 529-561.

Høyer, J. L., and D. Quadfasel (2001), Detection of deep overflows with satellite altimetry, Geophys. Res. Lett., 28(8), 1611-1614.

Jackett, D. R., and T. J. McDougall (1985), An oceanographic variable for the characterization of intrusions and water masses, Deep Sea Res., Part A, 32(10), 1195-1207.

Johnson, G. C. (2008), Quantifying Antarctic bottom water and North Atlantic deep water volumes, J. Geophys. Res., 113, C05027 doi: 10.1029/2007JC004477.

Johnson, G. C., and T. B. Sanford (1992), Secondary circulation in the Faroe Bank Channel outflow, J. Phys. Oceanogr., 22, 927-933.

Jones, C., E. Creed, S. Glenn, J. Kerfoot, J. Kohut, C. Mudgal, and O. Schofield (2005), Slocum gliders-A component of operational oceanography, in Proceedings of the 14th International Symposium on Unmanned Untethered Submersible Technology, Auton. Undersea Syst. Inst., Lee, N. H.

Martin, J. H. A. (1993), Norwegian Sea intermediate water in the FaroeShetland Channel, ICES J. Mar. Sci., 50, 195-201.

Mauritzen, C., J. Price, T. Sanford, and D. Torres (2005), Circulation and mixing in the Faroese Channels, Deep Sea Res., Part I, 52, 883-913.

Meincke, J. (1978), On the distribution of low salinity intermediate water around the Faroes, Deut. Hydrogr. Z., 31, 50-64.

Nicholson, D. (2009), Nitrogen, Oxygen, and the Noble Gases as Tracers of Upper-Ocean Productivity and Air-Sea Gas Fluxes, PhD dissertation, Univ. of Washington, Seattle, Wash.
Nicholson, D., S. Emerson, and C. C. Eriksen (2008), Net community production in the deep euphotic zone of the subtropical North Pacific gyre from glider surveys, Limnol. Oceanogr. Methods, 53, 2226-2236.

Perry, M. J., B. S. Sackmann, C. C. Eriksen, and C. M. Lee (2008), Seaglider observations of blooms and subsurface chlorophyll maxima off the Washington coast, Limnol. Oceanogr. Methods, 53, 2169-2179.

Read, J., and W. Gould (1992), Cooling and freshening of the subpolar North Atlantic Ocean since the 1960s, Nature, 360, 55-57.

Sarafanov, A., A. Falina, H. Mercier, A. Sokov, P. Lherminier, C. Gourcoff, S. Gladyshev, F. Gaillard, and N. Daniault (2012), Mean fulldepth summer circulation and transports at the northern periphery of the Atlantic Ocean in the 2000s, J. Geophys. Res., 117, C01014, doi: 10.1029/2011JC007572.

Saunders, P. M. (1990), Cold outflow from the Faroe Bank Channel, J. Phys. Oceanogr., 20, 29-43.

Schofield, O., et al. (2007), Slocum gliders: Robust and ready, J. Field Robotics, 24, 473-485, doi:10.1002/rob.20200.

Seim, K. S., and I. Fer (2011), Mixing in the stratified interface of the Faroe Bank Channel overflow: The role of transverse circulation and internal waves, J. Geophys. Res., 116, C07022, doi:10.1029/2010JC006805.

Stoll, M. H. C., H. M. van Aken, H. J. W. de Baar, and M. Kraak (1996), Carbon dioxide characteristics of water masses in the northern North Atlantic Ocean, Mar. Chem., 55, 217-232.

Talley, L. D., and M. S. McCartney (1982), Distribution and circulation of Labrador Sea Water, J. Phys. Oceanogr., 12, 1189-1205.

Thurnherr, A. M. (2011), How to Process LADCP Data With the LDEO Software (version IX.7). [Available at ftp://ftp.ldeo.columbia.edu/pub/ ant/LADCP/UserManuals/how-to/howto_2008_07_09.pdf.].

Turrell, W. R., G. Slesser, R. D. Adams, R. Payne, and P. A. Gillibrand (1999), Decadal variability in the composition of Faroe Shetland Channel Bottom Water, Deep Sea Res., Part I, 46, 1-25.

van Aken, H., and G. Becker (1996), Hydrography and through-flow in the north-eastern North Atlantic Ocean: the NANSEN project, Prog. Oceanogr., 38, 297-346.

van Aken, H. M., and C. J. de Boer (1995), On the synoptic hydrography of intermediate and deep water masses in the Iceland Basin, Deep Sea Res., Part I, 42(2), 165-189. 